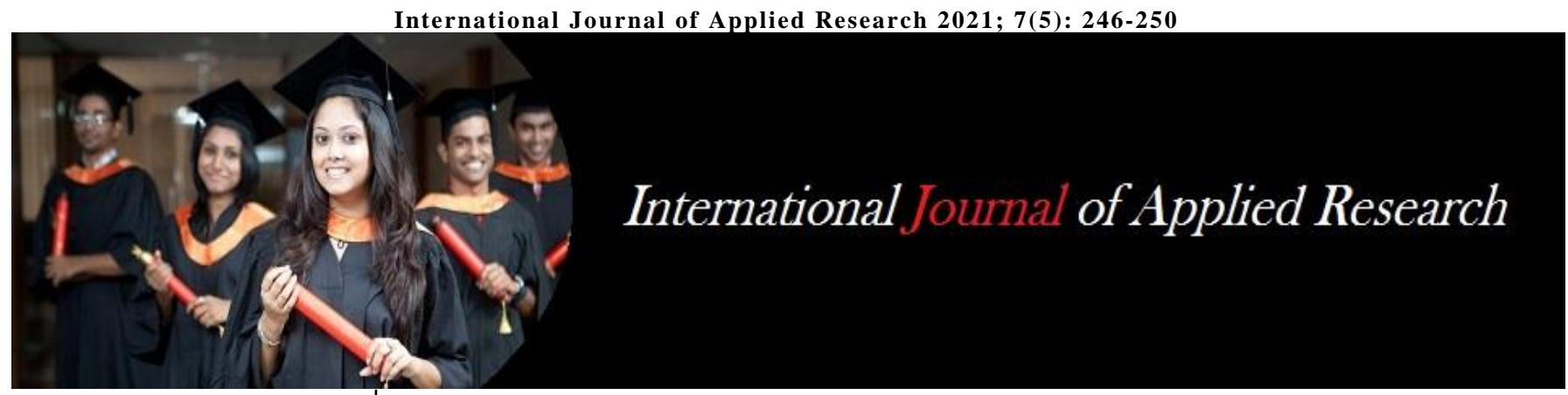

ISSN Print: 2394-7500 ISSN Online: 2394-5869 Impact Factor: 8.4 IJAR 2021; 7(5): 246-250 www.allresearchjournal.com

Received: 14-03-2021 Accepted: 21-04-202

Bakhtaver Hassan

Visiting Faculty, Amity School of Economics, Research Scholar, Amity University,

Noida, Uttar Pradesh, India

Mahua Bhattacharjee Professor, Amity School of Economics Amity University, Noida, Uttar Pradesh, India

Shabir Wani

Head of Department,

Department of Agricultural

Management and Horti-

Business, SKUAST-K,

Srinagar, Jammu and

Kashmir, India
Corresponding Author: Bakhtaver Hassan

Visiting Faculty, Amity School of Economics, Research

Scholar, Amity University,

Noida, Uttar Pradesh, India

\section{Post-harvest management inadequacy and its impact on apple industry in Kashmir}

\author{
Bakhtaver Hassan, Mahua Bhattacharjee and Shabir Wani
}

DOI: https://doi.org/10.22271/allresearch.2021.v7.i5d.8577

Abstract

This paper intends to study that the current post-harvest management of apple industry in Jammu and Kashmir. Apple contributes 60-65 percent to the total horticultural crop production in Jammu \& Kashmir from an acreage of over 50 percent. In terms of value of output, 70 percent of the total value of output in horticulture comes from apple alone. Secondary Data from National Horticulture Board, Directorate of Horticulture, Jammu \& Kashmir was used to highlight the problems which hinder the horticulture sector to reach to its potential. The paper found that that poor harvesting technique, poor marketing intelligence, inadequate storage facilities, lack of technological development and insufficient and inefficient marketing infrastructure are major hindrances in apple industry in the region. Further, there are no CA (Controlled Atmosphere) facilities in some of major horticulture producing districts of the region and the quantity of the produce stored in these CA facilities does not suffice the need of the market. Annually there is aggregate loss of 23000 crores of horticultural crops during post-harvest management like transportation, delays due to high intermediaries. Due to poor storage and infrastructure facilities, the producer attempts to dispose-off the produce quickly in the shortest possible time. This negates his capacity to hold the stock for better prices during off-season and leads to a natural slump in the market prices. Poor marketing intelligence among the farmers and lack of proper grading and sorting at the harvesting stage affects the marketing of the quality apple from the region. This overall impact the farmers' remuneration. Extended storage facilities in the potential areas at the block level or district level, proper training to the farmers for grading and sorting during harvesting may prove beneficial to the sector.

Keywords: Post-harvest management, controlled atmosphere, storage facilities, grading, sorting

\section{Introduction}

The Government of India acknowledged the importance of Horticulture during mid-eighties by asserting that there is need for diversification of agriculture on account of falling productivity and growing stagnancy of the sector. This was followed by focusing its attention on investment in the sector (Mittal, 2007) ${ }^{[12]}$. Overtime, Horticulture has surpassed the production of the food-grains alongside the productivity (Dastagiri et al, 2013) ${ }^{[3]}$. With rising income levels and changing dietary habits due to rapid urbanization (33\% urban population) alongside the sustainability of the horticultural sector, horticulture is significantly important for agri-industrial growth of the country. Presently, Horticulture contributes nearly $33 \%$ of the Agricultural GDP and the CAGR is nearly $2.6 \%$ since 2012, double the CAGR of food-crops. India is the second largest producer of fruits and vegetables in the world and its presence in the global market is significant (Horticulture at a Glance, 2018) ${ }^{[6]}$.

In Jammu and Kashmir, horticulture contributes significantly to the agricultural GDP as well as is one of prime-drivers of employment in the state. Nearly seven lakh families are directly or indirectly involved in the sector (Directorate of Horticulture, Jammu and Kashmir, Hassan et $a l, 2020)^{[7]}$. However, the efficiency of horticulture remains an Achilles- heel for the farmers. With mounting challenges of climate-change, growing population and diminishing land quality horticulture sector needs improvement in terms of technology, infrastructure and marketing mechanisms. 
Annually, 23000crore of food perishes due to poor transportation and with hilly states the figure climbs further (Economic Survey, Jammu and Kashmir, 2017-18).

Subsequent to the favorable agro-climatic conditions, there has been continuous progress of area under apple cultivation in the state from 88.15 (000) hectares in 2000-01 to 164.12 (000) hectares in 2015-16 (Bhat and Choure, 2014) ${ }^{[1]}$. The upswing in the acreage and the production is mainly due to comparative advantage of this crop over other commercial crops grown in the state. There have been fluctuations in the production during 2012-13 and 2014-15 because of erratic weather and low temperature, followed by floods in the Valley.

The productivity of most of the temperate fruits grown in Jammu and Kashmir State is much higher than other states cultivating these fruit crops. The productivity of apple in the state is 11.43 tonnes per hectare, which is much higher than the national average, and compares well with the world average of 10.82 tonne per hectare (Hassan et al, 2020) ${ }^{[7]}$. Infact the average yield of apple has been about 21.00 tonne per hectare in Baramulla district, which compares well with the yield of some European countries (Naqash, 2015) ${ }^{[13]}$. With the adoption of modern and innovative technologies, the prospects of increasing the productivity of fruits are very high. The flat lands or the lands with slight gradient have potential for high-density plantation, which besides increasing productivity will also increase employment opportunities and ensure judicious use of inputs. The state has a long harvesting season extending from July to November, ensuring supply of temperate fruits especially apple for more than six months. Other states, even though harvest their apple earlier, do not cater to the needs of the market for such an extended period as their harvesting period is short.

Table 1: Growth Pattern of Apple in Production and Area

\begin{tabular}{|c|c|c|c|c|c|}
\hline S. No & Year & $\begin{array}{c}\text { Apple Cultivation } \\
(\mathbf{0 0 0 H a})\end{array}$ & $\begin{array}{c}\text { Apple Production (00 } \\
\mathbf{M T})\end{array}$ & $\begin{array}{c}\text { Percentage Increase (Area } \\
\text { Wise) }\end{array}$ & $\begin{array}{c}\text { Percentage Increase (Production } \\
\text { wise) }\end{array}$ \\
\hline 1. & $2000-01$ & 88.15 & 751.31 & Base Year & Base Year \\
\hline 2. & $2001-02$ & 90.08 & 909.58 & 2.19 & 21.06 \\
\hline 3. & $2002-03$ & 94.87 & 953.95 & 7.62 & 26.97 \\
\hline 4. & $2003-04$ & 100.70 & 1041.54 & 14.24 & 38.63 \\
\hline 5. & $2004-05$ & 107.93 & 1093.28 & 22.44 & 53.52 \\
\hline 6. & $2005-06$ & 111.88 & 1151.71 & 26.92 & 62.29 \\
\hline 7. & $2006-07$ & 119.04 & 1222.18 & 35.04 & 74.61 \\
\hline 8. & $2007-08$ & 127.80 & 1311.85 & 44.98 & 77.40 \\
\hline 9. & $2008-09$ & 133.19 & 1332.81 & 51.09 & 82.74 \\
\hline 10. & $2009-10$ & 138.19 & 1372.97 & 56.77 & 146.55 \\
\hline 11. & $2010-11$ & 141.72 & 1852.41 & 60.77 & 133.75 \\
\hline 12. & $2011-12$ & 154.72 & 1756.19 & 75.52 & 79.44 \\
\hline 13. & $2012-13$ & 157.28 & 1348.15 & 78.42 & 119.31 \\
\hline 14. & $2013-14$ & 160.87 & 1647.69 & 82.50 & 55.71 \\
\hline 15. & $2014-15$ & 163.43 & 1170.30 & 85.40 & 161.73 \\
\hline 16. & $2015-16$ & 164.12 & 1966.41 & 86.10 & \\
\hline
\end{tabular}

Source: Directorate of Horticulture, Planning and Marketing, J\&K

\section{Literature review}

In 2018-19 the production of Apple from the region was 19 lakh tonnes, which is 77 percent of the total apple production in the country (Ministry of Agriculture, GOI). Annual export of apple from Kashmir fetches 7500 crores INR which is substantial for the state exchequer (Shaheen, Wani \& Kubrevi, 2019) ${ }^{[10]}$. Shah (1986), highlighted that the state despite being the largest apple producing state in the country has not reached its full potential due to lack of marketing information and techniques. Proper market information should be dispensed to ensure that farmers get better remuneration. Jammu and Kashmir is far ahead than Himachal Pradesh in apple production annually. Besides, the apples from the state are much tastier than their counterparts however; they still do not fetch the price of their counterparts (Bhat and Choure, 2014) ${ }^{[1]}$. Lack of coldstorage facilities, poor price-risk distribution among the growers and contractor, no proper market information among the farmers and negligible value addition in the supply chain further plague the growth of Apple Production of the Valley (Malik, 2013) ${ }^{[11]}$. Lack of government efforts, proper infrastructure like irrigation, poor research base within the region and lack of proper labour during the peak season are the major impeding factors for low productivity of apple in the valley (Bhat and Choure, 2014) ${ }^{[1]}$.
Transport vehicles should be developed accordingly to maintain proper environment for precooled commodities to overcome the long-travel and the climate-dependent road connectivity from Kashmir Valley to rest of the country (Kader, 2002) ${ }^{[9]}$. Use of cold-storages led to a decrease of 28 percent microbial growth which helped to reduce perishability of the apple crop (Ilyas et al. 2007). Marketing System of Apple Industry in Kashmir is disorganized and it is primarily due to lack of proper attention to the sector, despite contributing significantly to the state Economy (Bhat et al, 2012) ${ }^{[1]}$.

\section{Data and Methodology}

The erstwhile state of Jammu and Kashmir is predominantly agrarian where horticulture plays a dominant role. The Union Territory is divided into Jammu and Kashmir(J\&K) Province; whereby horticultural crops are majorly cultivated in Kashmir Region. To understand the present problems of horticultural sector in general and post-harvest management in particular, secondary data from Horticulture Department, Jammu and Kashmir, Economic Survey of J\&K and India and Reports from National Horticultural Board were used. The data was analyzed to assess the production of the apple crop in the state, current market infrastructure and cold storage facilities available in the market. Secondary data 
from Directorate of Horticulture, Jammu and Kashmir was used to assess the current marketing mechanism prevalent in the region. Along with, simple descriptive statistics were used to evaluate the present condition of the grading, processing and the prevalence of cold-storages for apple crop development.

\section{Objectives of the study}

1. To identify the current levels of grading and sorting of apples in the market and to understand the impact of this irregular grading on the remuneration of the grower.

2. To identify the present cold storage and controlled atmosphere facilities in the region and the economics of having cold storage facilities at different levels to prevent post-harvest losses of apple.

3. Current market availability and infrastructure of apple industry.

\section{Results and Discussion \\ Fundamentals of post-harvest management}

Frequency of irrigation, fertilizers, pest control management, climatic regulators, tree age, planting method and production are some of the pre-harvest factors influencing the post-harvest fruit quality and therefore remuneration of the grower. Appropriate information dissemination and proper training to the farmers can usually control these factors. Similarly, post-harvesting factors like harvesting method, harvest time, collecting tools, precooling, grading, sorting, packaging and transportation affect the fruit quality immensely. Furthermore, transportation efficiency, adequate storage facilities and infrastructure availability for marketing affect the quality of the produce. Efficient post-harvest management usually minimizes the perishability of the produce, increases the shelf life and quality, which leads to better productivity and remuneration among the farmers.

\section{Harvesting apples at optimum maturity}

Time is certainly a crucial factor for apple harvesting to minimize the perishability of the apple produce. Harvesting the produce when they are physiologically mature is critical to achieve maximum storage life and marketing season. Apples harvested early are usually discolored, small size and have lower taste quality than the normal ones. They ripen abnormally or fail to ripen at all which affect their overall quality. These immature, ill-ripened apples show characteristics of inadequate flavour, high water losses, high acidity and low aroma and tend to develop storage disorders such as superficial scald and bitter pit. At the other side, harvesting apples at the lateral stage shorten their storage life and are more prone to disease infection. Therefore, optimum apple maturity for harvesting is important for maximizing storage, life and quality while minimizing postharvest losses. Meanwhile, different varieties of apples mature and ripen at different time. It is important for the farmer to understand this to ensure that his quality is not compromised.

\section{Grading and Sorting}

Grading is the process of separation of apple into groups of homogenous size, color and free from any disorders, which play an important role in marketing of these apples. Size Grading, Colour Grading and other quality grading is usually done at the time of packaging. Grading stimulates the farmer to produce and pushes the trader to maintain a high quality of the produce throughout the supply chain to eventually benefit the consumer. It increases the saleability of the apple produce as the consumer is assured of the quality he is paying for. It is usually witnessed that packing and grading of apples scientifically fetches $25-55 \%$ more than the traditionally graded apples. NAFED in collaboration with Department of Horticulture Marketing and Planning have categorized Kashmiri Apples into three main grades- A, B and C. However, there is widening gap among the farmers to understand the real grading process and economics of it. Grading is usually considered at the some of the markets were it is done manually with no prescribed standards. The packaging of Grade A apple with Grade B and C apples mitigates the value of high grade and high quality apples from the region. As such, the farmers get low remuneration as well as affects the overall standardization of the apple quality coming out from the region into the Indian value chain.

At present packing and grading houses with the capacity of 40,000 tonnes of apples are operating in Baramulla, Pulwama, Kulgam, Budgam and Anantnag districts of the region. With nearly 25 grading houses present in the Valley, it caters to nearly $20 \%$ of the apple production. This is very low as compared to the developed European Markets where nearly $80-90 \%$ of the produce comes under standard grading houses. Inferior grading is the prime reason for lower bargaining power of the traders and therefore lower prices received by the farmers.

\section{Packaging}

Packaging goes a long way in maintaining the quality of products and the goods in the movement through the supply chain. It is critical for sales promotion, which should be used well for the promotion and safety of quality apple production. The state faces a significant problem in the packaging of apple produce annually. Every year 2.5-3 million cubic feet of timber is used for packing of fruit in the erstwhile state. This timber packaging system is proven short-lived and uneconomical. To overcome, cardboard cartons were deployed few years back to bring efficiency as well ensure that there is adequate packaging standardization contemplated. However, road connectivity, delays in transportation, lack of adequate storage facilities and poor handling techniques have rendered them ineffective in maintaining the quality of the apples. Further, this arrangement does not cater to the needs of small and marginal farmers as these farmers opted out from this system due to higher cost of cardboard cartons. It is pertinent to mention that efficient marketing of apple needs development and adoption of suitable packaging to ensure that quality is not compromised to any extent.

\section{Cold storage and controlled atmosphere facilities}

Apple Production in the Valley needs adequate storage facilities to ensure proper physical distribution of the produce into the market. During the harvest season, there is glut in the market, which lowers the price of the apple produce, due to poor infrastructure of packaging, insufficient and inefficient transportation and inadequate storage facilities. The outflow from the Valley in the country is usually during September to December. If there are adequate storage facilities available, the farmers can 
delay this outflow until March-May of the next year and take advantage of the real market value of their produce. At present, unfortunately all the 18 operational cold storages with a capacity of nearly $50000 \mathrm{MT}$ in the erstwhile State are located in Jammu. Approximately, $30 \%$ of the apple produce is stored in these cold storage facilities during the peak season. In the Valley, there are 8 Controlled Atmosphere Facilities available at present which possess a carrying capacity of $38000 \mathrm{MT}$. (Table 2) During the peak season, $60 \%$ of the capacity is utilized and the throughout the year only $40 \%$ of the capacity is properly utilized. The reasons for this under-utilization are due to lack of awareness about grading, packaging and storage facilities as well inadequate marketing information among the farmers.

Table 2: Controlled Atmosphere Facilities in Jammu and Kashmir

\begin{tabular}{|c|c|l|c|}
\hline $\begin{array}{c}\text { S. } \\
\text { No }\end{array}$ & Name of the CA Facility & \multicolumn{1}{c|}{ Location } & $\begin{array}{c}\text { Capacity } \\
\text { (MT) }\end{array}$ \\
\hline 1. & Valley Fresh Cold Chain Pvt. Limited & Lassipora, Pulwama & 5000 \\
\hline 2. & I-Fresh Kehwa Square Pvt. Limited & Lassipora, Pulwama & 5000 \\
\hline 3. & Golden Apple Agro Fresh Pvt. Limited & Lassipora, Pulwama & 2000 \\
\hline 4. & Harsha Natural Agri Service Pvt. Ltd & Lassipora, Pulwama & 5000 \\
\hline 5. & Fruit Master Agro Fresh Pvt. Ltd. & Lassipora, Pulwama & 5000 \\
\hline 6. & Shaheen Agro Fresh Pvt. Ltd & Lassipora, Pulwama & 5000 \\
\hline 7. & Kashmir Premium Apples Pvt. Ltd & Lassipora, Pulwama & 5000 \\
\hline 8. & FIL Industries Pvt. Ltd & Rangreth, Budgam & 5000 \\
\hline
\end{tabular}

Source: Directorate of Horticulture Marketing and Planning
Besides, the problem of facility of cold storage is offered to farmers who are registered with the corporation. The facility of cold storage facilities will ensure that the farmer receives maximum economic returns from apple trade by adjusting the timing of the sale according to the market feasibility. Cold storage facilities will therefore extend the export of apple produce to 6-8 months from current 3-4 months. It will henceforth, reduce the oligopolistic market structure in the region and also enhance the bargaining power of the farmers as well as traders by bringing back control of the market in their hands.

\section{Marketing of Apple}

Marketing is the fundamental link between farm sector income and production of the farmer. Efficient marketing is likely to build a strong linkage between the income of the farmers and the farm production while there is a strong negative correlation between farm income and farm production in inefficient marketing. Furthermore, the distribution or the supply chain in the marketing channel of apple is highly essential to ensure that the avenue is successful and profitable. Looking at the supply chain of the apple-marketing channel, we observe a pyramid of farmers producing apple, traders, commission agents or intermediaries and consumers.

Table 3: Terminal Markets in Jammu and Kashmir

\begin{tabular}{|c|c|c|c|c|}
\hline S. No & Terminal Market & Area Covered & Number of Commission Agents & Number of Buyers outside State \\
\hline 1. & Parimpora, Srinagar & 320 Kanals & 260 & 27 \\
\hline 2. & Betingoo, Anantnag (Non Operational) & 56 Kanals & NA & NA \\
\hline 3. & Kulgam (Non-Operational) & 40 Kanals & NA & NA \\
\hline 4. & Narwal, Jammu & 374 Kanals & NA & NA \\
\hline 5. & Pulwama (Non-Operational) & 34 Kanals & NA & NA \\
\hline 6. & Shopian (Non-operational) & 32 Kanals & NA & NA \\
\hline 7. & Zaloosa, Budgam (Non-Operational) & 48 Kanals & 240 & 40 \\
\hline 8. & Sopore, Baramulla & 462 Kanals & \\
\hline
\end{tabular}

Source: Directorate of Horticulture Marketing and Planning, Jammu and Kashmir.

Presently, the marketing of apple is characterized by transport inadequacy that runs inefficiently in the distribution channel. Poor marketing information amongst the farmers, lack of proper connectivity, rough roads and high number of intermediaries further render the distribution channel inefficient. There is widening gap between the farm-gate prices and the price at which consumers get their product as the intermediaries primarily earn the most in the distribution channel. Around $30 \%$ of the apple produce is marketed through Producer-Commission AgentWholesaler- Retailer- Consumer (P-A-W-R-C) which is considered as one of the inefficient supply chains in horticultural marketing (Dastagiri).

According to the data of Directorate of Horticulture Marketing and Planning, the marketing channels is not adequately developed and the market even today is disintegrated with only 8 terminal markets out of which only three markets are fully functional. The catchment area of these terminal markets is very large and even all these markets are fully functional it will not cater to the total production from the region. Moreover, till now no corporate or industry has been established in Kashmir to link horticulture to the industrial development. Even marketing of Kashmiri Apples has severely been affected by the cheaper and higher quality of apples available from Himachal Pradesh.

\section{Conclusion}

In view of the current post-harvest management of apple crop in Kashmir, there are visible problems of poor cultivation practices, lack of proper guidelines regarding cultivation, poor information dissemination of weather forecasting and poor information regarding soil health. Although the productivity of apple crop in the region is highest in the country, it still is far behind than the European standards. Harvesting loses are very high in the region due to poor skills of the growers and labourers. Even after harvesting, the region has poor connectivity and insufficient and inefficient transportation facilities. Packaging of apples is not scientifically beneficial to the produce and cardboard packaging is not economically beneficial to small and marginal farmers. Transportation of apples into country market peaks from September to December, which creates a market glut due to poor stocking by the farmers and traders. Added to this, poor storage facilities and delay in the proposed terminal markets further constraint the coldstorage infrastructure in the region, leading to high perishability of around 23000 crores in one year. Nearly 1025 percent of the crops are perished in this way. Besides lack of storage facilities affects quality of the produce, which eventually affects the marketing of the apple from the region. Therefore, there is need for a coordinated approach 
to bring efficiency in the post-harvest management. This includes:

1. Skilling of the farmers regarding harvesting and providing proper agricultural extension to the farmers at the block or the village level. This mandates creation of Farmer Producer Organisation or forums to bring parity among farmers regarding quality information dissemination. Training Centers would ensure that the farmer is given appropriate knowledge regarding the optimum harvesting time.

2. Enhancing Market intelligence and dissemination of market information to the farmers at the right time is also critical to ensure that the farmers' get a headstart before the harvesting season.

3. Training to the growers is imperative in grading and sorting of the produce. Proper grading can result in increase of $25-50 \%$ of the revenue and lead to better marketing. Therefore, storage facilities should be rightly provided with appropriate grading arrangements.

4. Government should bring in the concept of cooperatives and leverage internet services to check the growing number of intermediaries or commission agents, which affect the market cost and eventually lead to high price spread.

5. Incentives for using cardboard cartons to small and marginal farmers can lead to better packaging of the produce.

6. Development of cold-storage facilities and utilizing the capacity of the already existing cold-storage facilities to the fullest will also ensure that the market glut during the peak harvesting time is arrested. This would ensure that the farmer or trader extends the stocks of their produce till 8 months, thus giving them better bargaining power, hence better remuneration.

7. Development of cold-storage at the Tehsil/ Block Level in accordance to the hub and spoke model of Agroparks will immensely help in preserving the quality of the produce leading to better livelihood.

8. Technological Advancement is also necessary in the post-harvest management. Use of Pack-House Concept and Controlled Atmosphere at the storage facilities is imperative to ensure that the quality of the produce is comparable to international standards.

Horticulture is the backbone of the agrarian economy of the erstwhile state. Therefore, Research and Design at the State Universities linked directed to the farmers' concern is also important to ensure that the sector stays at the fulcrum of our Economy.

\section{References}

1. Bhat TA, Choure T. Status and strength of apple industry in Jammu and Kashmir. International Journal of Research 2014;1(4):277-283.

2. BHAT JA, Aara RR. Marketing Efficiency of Kashmir Apple. Marketing 2012;35(227.17):50-64.

3. Dastagiri MB, Chand R, Immanuelraj TK, Hanumanthaiah CV, Paramsivam $\mathrm{P}$, Sidhu $\mathrm{R}$ et al. Indian vegetables: production trends, marketing efficiency and export competitiveness 2013.

4. Government of India, Ministry of Finance, Economic Survey, 2018-19. Agriculture and Allied Sectors.

5. Government of Jammu and Kashmir, India, Directorate of Horticulture, 2019-20.
6. Government of India, Ministry of Statistics Planning and Implementation, National Horticulture Board, Horticulture at a Glance, 2018.

7. Hassan B, Bhattacharjee M, Wani SA. Economic analysis of high-density apple plantation scheme in Jammu and Kashmir. Asian Journal of Agriculture and rural Development 2020;10(1):379-391.

8. Hanan E. Entrepreneurship perspective for trade and management of horticulture sector in Kashmir Himalayan valley. International Journal of Social Sciences and Management 2015;2(3):284-289.

9. Kader AA, Rolle RS. The role of post-harvest management in assuring the quality and safety of horticultural produce. Food \& Agriculture Org 2004, 152.

10. Shaheen FA, Wani SA, Kubrevi SS. The landscape of agro-processing industries in Jammu \& Kashmir. Agricultural Economics Research Review 2019;32:175182.

11. Malik ZA. Assessment of apple production and marketing problems in Kashmir valley. Journal of Economic \& Social Development 2013;9(1):152-156.

12. Mittal S. Can horticulture be a success story for India?. Working paper 2007, 197.

13. Naqash F. A Value Chain Analysis of Apple in Jammu and Kashmir Doctoral dissertation, SKUAST Kashmir 2015. 